\title{
Knowledge, Attitude and Practice on Prevention of Catheter-Associated UTI Among Nurses of a Tertiary Care Hospital
}

\author{
Rashmi K.C.' ', Binita Dhakal' \\ 'Nursing Program, College of Medical Sciences - Teaching Hospital, Bharatpur-10, Chitwan, Nepal.
}

\begin{abstract}
Introduction

Urinary tract infection (UTI) is among the common bacterial infections worldwide and approximately $80 \%$ are associated with a urinary catheter. Catheter-associated UTI (CAUTI) has been associated with increased mortality, morbidity, length of hospital stay and the best way of CAUTI prevention is to adhere to recommended guidelines on infection control in the use of a urinary catheter.
\end{abstract}

\section{Methods}

An analytical cross-sectional study was conducted among the nurses of college of medical sciences. A total of 160 staff nurses were selected using a probability simple random sampling technique. Data was collected using a self-administered questionnaire for knowledge, Likert scale for attitude, and checklist for practice regarding the prevention of CAUTI. The data gathered was analyzed using both descriptive and inferential statistics in SPSS software.

\section{Results}

Research revealed that among 160 nurses 59.37\% had a moderate level of knowledge and only $16.25 \%$ had an adequate level of knowledge towards the prevention of CAUTI. The positive level of attitude of nurses was $41.88 \%$ and the majority of nurses $64.38 \%$ had a good level of practice. Also, age $(p=0.022)$, professional qualification $(p=0.001)$, designation $(p=0.001)$, current area of practice $(p=0.030)$, and previous information towards CAUTI prevention $(p=0.003)$ among all the socio-demographic variables were statistically significant with the level of knowledge regarding the prevention of CAUTI.

\section{Conclusions}

Majority of nurses level of knowledge was not satisfactory and had a negative attitude regarding CAUTI prevention. Statistically significant variables with level of knowledge are age, professional qualification, designation, area of practice.

Keywords: CAUTI; UTI; attitude; catheter-associated urinary tract infections; practice

Correspondance: Rashmi K.C., Nursing Program, College of Medical Sciences - Teaching Hospital, Bharatpur-10, Chitwan, Nepal. Email: rashmikc19@gmail.com. Phone: +977-9845920629. 


\section{INTRODUCTION}

Urinary catheterization is a procedure that must be done under aseptic technique by qualified nurses otherwise it can cause infection. Urinary tract infections are among the most common bacterial infections worldwide and represent approximately $40 \%$ of hospital-acquired infections, with significant consequences for morbidity and mortality and substantial financial burden. Among UTIs acquired in the hospital, approximately $75 \%$ are associated with a urinary catheters. ${ }^{1}$

The factors significantly associated with CAUTI include the duration of catheterization. ${ }^{3}$ Shortening the duration of catheterization, avoiding unnecessary urethral catheterization and using sterile precautions in the insertion and maintenance of indwelling catheters can reduce catheter-related complications. ${ }^{4}$ Indwelling catheters placement is aimed to relieve obstructive urinary symptoms and despite their symptomatic benefit, they are often implicated in causing recurrent UTI. ${ }^{2}$ The incidence of device-associated infections in the intensive care unit of developing countries was high compared with that of developed countries and it is important to formulate and implement the standard infection control protocols. ${ }^{5}$

Nurses are the primary managers of all the routine care and problem-solving associated with patients who have indwelling urinary catheters. Thus, this study aims to assess the nurse's knowledge, attitude and practice towards the prevention of CAUTI.

\section{METHODS}

Analytical cross-sectional study was conducted among the nurses of College of Medical SciencesTeaching Hospital, Bharatpur-10. A study conducted by Kumar showed that $46.7 \%$ of staff nurses had adequate knowledge of catheter care $^{9}$. By considering this as a prevalence, taking a $5 \%$ level of significance (the z-score value at $95 \%$ Confidence interval is 1.96), with a $5 \%$ margin of error. Sample size was calculated by using the formula $(n)=z^{2} p q /\left(e^{2}+z^{2} p q / N\right)$.

By adding a $10 \%$ non-response rate, the optimum sample size of this research was 160 . Before the main study, the pre-test was conducted among $10 \%$ of the nurses, and the reliability of the tool was checked by Cronbach's alpha in SPSS. Then, this questionnaire was distributed among nurses using the Probability Sampling technique (random number table). Self-administered semistructured questionnaire with 20 questions was used to assess knowledge, 5-point Likert scale to assess attitude, and checklist to assess practice for data collection. Ethical approval was taken from the Institutional Review Committee Board of College of Medical Sciences and Teaching Hospital (Ref.No.2019-006). Collected data was checked, reviewed, organized for accuracy and completeness, and coded before entry. Data were entered into the Excel and statistical package for the social sciences (SPSS-A software designed for data entry) version 20.0. In descriptive statistics, the result was presented using frequency, percentage, tables, mean and in the inferential statistics, Chi-square test was used to find the association between the level of knowledge with related variables.

A scoring system was used where 1 point was given for each correct response to knowledge and good practices. For positive attitude, strongly agree $=5$, agree $=4$, uncertain $=3$, disagree $=2$, and strongly disagree $=1$ and reverse scoring for negative attitude. The cut-off values to determine the level of knowledge, attitude and practice were taken from previously published studies. A score greater than $70 \%$ was considered to have adequate knowledge, 50\%-70\% moderate knowledge, and less than 50\% inadequate knowledge. ${ }^{6}$ Also, positive attitude ( $>$ mean 
score) and negative attitude ( $\leq$ mean score).$^{7} \mathrm{~A}$ score between $61-100 \%$ was considered as good practice and $0-60 \%$ poor practice. ${ }^{8}$

\section{RESULTS}

The socio-demographic findings show that out of 160 nurses, the majority of the respondents $56.25 \%$ were from the age group 19-24 years. Regarding the professional qualification, $66.25 \%$ had PCL nursing degree, and nearly two-thirds of nurses $67.5 \%$ had $1-5$ years of working experience. Regarding the information or training on CAUTI prevention, the majority of the nurses $65 \%$ had no information or not attended any training on CAUTI prevention. Only $13.75 \%$ of the nurses got information on prevention of CAUTI by their work experience (Table 1)

Table 1. Socio-demographic Characteristics of the nurses. $(n=160)$

\begin{tabular}{|c|c|c|}
\hline Demographic variables & $\begin{array}{c}\text { Frequency } \\
\text { (f) }\end{array}$ & $\begin{array}{c}\text { Percentage } \\
(\%)\end{array}$ \\
\hline \multicolumn{3}{|l|}{ Age (in years) } \\
\hline $19-24$ & 90 & 56.25 \\
\hline $25-30$ & 60 & 37.5 \\
\hline $31-35$ & 10 & 6.25 \\
\hline
\end{tabular}

\begin{tabular}{|l|c|c|}
\hline Professional Qualification & & \\
\hline ANM Nursing & 2 & 1.25 \\
\hline PCL Nursing & 106 & 66.25 \\
\hline Bachelor of Nursing (BN) & 24 & 15 \\
\hline $\begin{array}{l}\text { Bachelor of Science in } \\
\text { Nursing (B.Sc. Nursing) }\end{array}$ & 28 & 17.5 \\
\hline Designation & 142 & 88.75 \\
\hline Staff Nurse & 18 & 11.25 \\
\hline Ward In-Charge & & \\
\hline $\begin{array}{l}\text { Duration of Working } \\
\text { Experience (in years) }\end{array}$ & 38 & 23.75 \\
\hline$<1$ & 108 & 67.5 \\
\hline $1-5$ & 8 & 5 \\
\hline $6-10$
\end{tabular}

\begin{tabular}{|l|c|c|}
\hline$>10$ & 6 & 3.75 \\
\hline Current Area of Practice & & \\
\hline Medical ward & 14 & 8.75 \\
\hline Surgical ward & 30 & 18.75 \\
\hline ICU / CCU & 84 & 52.5 \\
\hline Emergency & 6 & 3.75 \\
\hline Pediatrics & 4 & 2.5 \\
\hline Obstetrics and Gynecology & 6 & 3.75 \\
\hline Others (Cabin, Dialysis, OT) & 16 & 10 \\
\hline $\begin{array}{l}\text { Previous information or } \\
\text { training on prevention of } \\
\text { CAUTI }\end{array}$ & & \\
\hline Yes & 56 & 35 \\
\hline No & 104 & 65 \\
\hline $\begin{array}{l}\text { Previous source of } \\
\text { information on the } \\
\text { prevention of CAUTI }\end{array}$ & 13 & 8.12 \\
\hline Nursing Curriculum & 22 & 13.75 \\
\hline Work experience & 9.63 \\
\hline Self-reading & 12 & 7.5 \\
\hline In-service education & & \\
\hline
\end{tabular}

Regarding the knowledge on each component of questions, nearly three quarters $(71.25 \%)$ of nurses know the meaning of CAUTI. Only $42.5 \%$ of nurses correctly responded to the appropriate indication of urinary catheterization. Most of the nurses $76.87 \%$ correctly responded that aseptic technique with sterile equipment should be used for indwelling urinary catheter insertion. However, only $33.12 \%$ of nurses correctly responded that they should change the catheter immediately if she found that the indwelling urinary catheter is obstructed during the patient assessment. More than half (58.12\%) of the nurses know that they should discontinue and start the procedure again using an aseptic technique if she forgets to put on sterile gloves before inserting a urinary catheter. Nearly one third $(36.87 \%)$ of the nurses know that placing the drainage bag above the bladder at all times increases the risk for CAUTI. Most of the nurses $54.37 \%$ know that catheters should be used if 
only when there is a clinical indication. Only $37.5 \%$ of the nurses know that routine irrigation of the bladder with an antimicrobial solution is unlike for preventing CAUTI (Table 2).

Table 2. Knowledge regarding the prevention of catheter-associated urinary tract infection.

\begin{tabular}{|l|c|c|}
\hline $\begin{array}{l}\text { Items } \\
\text { CAUTI is a UTI resulting from } \\
\text { the presence of an indwelling } \\
\text { urinary catheter for a } \\
\text { prolonged duration of time. }\end{array}$ & 114 & 71.25 \\
\hline $\begin{array}{l}\text { Escherichia coli are the } \\
\text { Common pathogens of CAUTI. }\end{array}$ & 99 & 61.87 \\
\hline $\begin{array}{l}\text { Prolonged time of } \\
\text { catheterization is a risk factor } \\
\text { for CAUTI. }\end{array}$ & 107 & 66.87 \\
\hline $\begin{array}{l}\text { Bacteriuria is the most common } \\
\text { complication of long-term } \\
\text { indwelling urinary catheters. }\end{array}$ & 76 & 47.5 \\
\hline $\begin{array}{l}\text { Aseptic technique with the } \\
\text { use of sterile equipment is } \\
\text { the proper technique used for } \\
\text { indwelling urinary catheter } \\
\text { insertion. }\end{array}$ & 123 & 76.87 \\
\hline $\begin{array}{l}\text { Within 24 hours after surgery, } \\
\text { the operative patients are } \\
\text { advised to remove the catheter- } \\
\text { based on CDC Guidelines for } \\
\text { the prevention of CAUTI. }\end{array}$ & 67 & 41.88 \\
\hline $\begin{array}{l}\text { Nurse should discontinue and } \\
\text { start the procedure again using } \\
\text { the aseptic technique if she } \\
\text { forgets to put on sterile gloves } \\
\text { before inserting a urinary } \\
\text { catheter. }\end{array}$ & 93 & 58.12 \\
\hline $\begin{array}{l}\text { Placing the drainage bag } \\
\text { above the bladder at all times } \\
\text { increases the risk for CAUTI. }\end{array}$ & 59 & 36.87 \\
\hline $\begin{array}{l}\text { Use catheters only when there } \\
\text { is a clinical indication is the } \\
\text { best method to prevent CAUTI. }\end{array}$ & 87 & 54.37 \\
\hline $\begin{array}{l}\text { Routine irrigation of the } \\
\text { bladder with an antimicrobial } \\
\text { solution is unlike for preventing } \\
\text { CAUTI. }\end{array}$ & 60 & \\
\hline
\end{tabular}

Regarding the practice, it is alarming that only $26.87 \%$ of the nurses perform hand hygiene before and after catheter manipulation. Only $29.37 \%$ of the nurses daily perform catheter care. Minimum $15.62 \%$ of the nurses use gown and clean gloves during any manipulation of the catheter or when you drain the collecting bag. Only $48.75 \%$ of nurses perform closed continuous irrigation when an obstruction is anticipated (Table 3).

Table 3. Practice on prevention of catheterassociated urinary tract infection.

\begin{tabular}{|l|c|c|}
\hline Practice & Frequency & $\%$ \\
\hline $\begin{array}{l}\text { The patient meets at least one } \\
\text { appropriate indications for } \\
\text { the catheterization. }\end{array}$ & 146 & 91.25 \\
\hline $\begin{array}{l}\text { Hand hygiene before and } \\
\text { after catheter insertion. }\end{array}$ & 145 & 90.62 \\
\hline $\begin{array}{l}\text { Hand hygiene before and } \\
\text { after catheter manipulation. }\end{array}$ & 43 & 26.87 \\
\hline $\begin{array}{l}\text { Use a sterile technique for } \\
\text { catheter insertion. }\end{array}$ & 133 & 83.12 \\
\hline $\begin{array}{l}\text { Insert urinary catheters only } \\
\text { when necessary for patient } \\
\text { care and leave in place only } \\
\text { as long as the indication } \\
\text { remains. }\end{array}$ & 110 & 68.75 \\
\hline $\begin{array}{l}\text { Inject sterile water into } \\
\text { needless port to inflate the } \\
\text { indwelling catheter balloon. }\end{array}$ & 160 & 100 \\
\hline $\begin{array}{l}\text { Secure indwelling catheters } \\
\text { after insertion to prevent } \\
\text { movement and urethral } \\
\text { traction. }\end{array}$ & 41 & 25.62 \\
\hline \begin{tabular}{l} 
Daily perform catheter care. \\
\hline $\begin{array}{l}\text { Maintain the closed system all } \\
\text { the time. }\end{array}$
\end{tabular} & 157 & 98.12 \\
\hline $\begin{array}{l}\text { Avoid contact with the } \\
\text { drainage tube outlet with the } \\
\text { collecting container or any } \\
\text { foreign materials. }\end{array}$ & 149 & 93.12 \\
\hline $\begin{array}{l}\text { Use gown and clean gloves } \\
\text { during any manipulation of the } \\
\text { catheter or when you drain the } \\
\text { collecting bag. }\end{array}$ & 25 & 15.62 \\
\hline
\end{tabular}




\begin{tabular}{|l|c|c|}
\hline $\begin{array}{l}\text { Use a separate collecting } \\
\text { container when emptying } \\
\text { the collecting bag for each } \\
\text { patient. }\end{array}$ & 27 & 16.87 \\
\hline $\begin{array}{l}\text { Perform closed continuous } \\
\text { irrigation when an obstruction } \\
\text { is anticipated. }\end{array}$ & 78 & 48.75 \\
\hline $\begin{array}{l}\text { Apply standard precautions } \\
\text { during catheter removal. }\end{array}$ & 133 & 83.12 \\
\hline $\begin{array}{l}\text { Document the date and time } \\
\text { of catheter insertion and } \\
\text { removal. }\end{array}$ & 120 & 75 \\
\hline
\end{tabular}

Our research showed that only $16.25 \%$ had an adequate level of knowledge on prevention of CAUTI, regarding attitude $41.88 \%$ had a positive attitude and $58.12 \%$ had a negative attitude whereas, regarding practice, $64.38 \%$ had a good level of practice regarding the prevention of CAUTI (Table 4). There was a statistically significant association between nurses level of knowledge and age $(\mathrm{p}=0.022)$, professional qualification (0.001), designation (0.001), current area of practice (0.030), and information or training on CAUTI prevention (0.003) (Table 5).

Table 5. Association between Levels of Knowledge with Sociodemographic Characteristics. $(n=160)$

\begin{tabular}{|c|c|c|c|c|c|c|c|c|}
\hline \multirow[t]{3}{*}{ Variables } & \multicolumn{6}{|c|}{ Level of knowledge } & \multirow[t]{3}{*}{ Chi-Square } & \multirow[t]{3}{*}{ P-value } \\
\hline & \multicolumn{2}{|c|}{ Adequate } & \multicolumn{2}{|c|}{ Moderate } & \multicolumn{2}{|c|}{ Inadequate } & & \\
\hline & $f$ & $\%$ & $f$ & $\%$ & $f$ & $\%$ & & \\
\hline \multicolumn{9}{|l|}{ Age (in years) } \\
\hline $19-24$ & 9 & 5.62 & 54 & 33.75 & 27 & 16.87 & \multirow[t]{2}{*}{7.629} & \multirow[t]{2}{*}{$0.022^{*}$} \\
\hline$>24$ & 17 & 10.63 & 41 & 25.63 & 12 & 7.5 & & \\
\hline \multicolumn{9}{|l|}{ Professional qualification } \\
\hline ANM Nursing & 0 & 0 & 1 & 0.63 & 1 & 0.63 & \multirow[t]{3}{*}{53.567} & \multirow[t]{3}{*}{$0.001 *$} \\
\hline PCL Nursing & 4 & 2.5 & 65 & 40.62 & 37 & 23.12 & & \\
\hline Bachelor in Nursing & 22 & 13.75 & 29 & 18.12 & 1 & 0.63 & & \\
\hline \multicolumn{9}{|l|}{ Designation } \\
\hline Staff Nurse & 17 & 10.62 & 86 & 53.75 & 39 & 24.37 & \multirow[t]{2}{*}{19.467} & \multirow[t]{2}{*}{$0.001 *$} \\
\hline Ward In-charge & 9 & 5.63 & 9 & 5.63 & 0 & 0 & & \\
\hline \multicolumn{9}{|l|}{ Total working experience (in years) } \\
\hline$<1$ & 6 & 3.75 & 18 & 11.25 & 14 & 8.75 & \multirow[t]{2}{*}{4.394} & \multirow[t]{2}{*}{0.111} \\
\hline$\geq 1$ & 20 & 12.5 & 77 & 48.13 & 25 & 15.62 & & \\
\hline \multicolumn{9}{|l|}{ Current area of practice } \\
\hline Medical ward & 6 & 3.75 & 6 & 3.75 & 2 & 1.25 & \multirow[t]{4}{*}{12.134} & \multirow[t]{4}{*}{$0.030 *$} \\
\hline Surgical ward & 3 & 1.87 & 15 & 9.38 & 12 & 7.5 & & \\
\hline ICU/CCU & 14 & 8.75 & 54 & 33.75 & 16 & 10 & & \\
\hline $\begin{array}{l}\text { Others (Emergency, Pediatrics, Obstetrics } \\
\text { \& Gynecology, Cabin, Dialysis, OT) }\end{array}$ & 3 & 1.87 & 20 & 12.5 & 9 & 5.63 & & \\
\hline \multicolumn{9}{|l|}{$\begin{array}{l}\text { Information or training on CAUTI } \\
\text { prevention }\end{array}$} \\
\hline Yes & 16 & 10 & 32 & 20 & 8 & 5 & \multirow[t]{2}{*}{11.719} & \multirow[t]{2}{*}{$0.003 *$} \\
\hline No & 10 & 6.25 & 63 & 39.37 & 31 & 19.38 & & \\
\hline
\end{tabular}




\section{DISCUSSION}

In this study, the highest $56.25 \%$ of the nurses were in the age group 19-24 years and similar findings have been depicted in a study conducted in India . ${ }^{9}$ In the present study, the majority of nurses $66.25 \%$ had completed PCL Nursing which was comparable to the study conducted in Pakistan where a maximum of nurses had their professional qualification as diploma nurses. ${ }^{10}$ The similarity in the result might be due to the more number of proficiency certificate nursing colleges. Most of the nurses $65 \%$ had got no information or training on the prevention of CAUTI. This is consistent with a study conducted in India that showed $71.7 \%$ of nurses had not attended the in-service education programme. ${ }^{11}$ This reflects there is a lack of inservice training and needed training on urinary catheter management which may have a significant impact on preventing CAUTI.

The findings of the present study indicated that most of the nurses $59.37 \%$ had a moderate level of knowledge. This is supported by the study conducted in India where $56.7 \%$ of nurses had moderate knowledge. ${ }^{11}$ The similarity in both the study may be due to nonadherence of nurses to infection prevention and not updated with the effective recommended guidelines regarding catheter care.

In this study, $58.12 \%$ of nurses had a negative attitude while only $41.88 \%$ had a positive attitude and is supported by the study conducted in Pakistan with a $60 \%$ negative attitude. ${ }^{12}$ This similarity might be because in both study majority of nurses were young and had a basic educational background, as nurses with higher qualifications, they are more likely to advance their knowledge through experience and gained a more positive attitude.

The result of this study revealed that most of the nurses $64.38 \%$ had a good level of practice.
The result is in line with a study conducted in Rwanda where a high percentage of nurses have shown a good implementation of different practices towards CAUTI prevention. ${ }^{7}$ This similarity might be because nurses were competent, uses their critical thinking and leadership skills in providing safe and quality nursing care clinically.

In this study, there was a significant association between the nurses level of knowledge and age $(p=0.022)$ which was in accordance with the study conducted in Saudi Arabia ${ }^{8}$. The similarity in the result might be attributed to the fact that as the nurses get older they are more likely to advance their knowledge through experience and working with senior staff. In the present study, information or training on CAUTI prevention was significant with nurses level of knowledge ( $p=0.003$ ) which is similar to the study conducted in Ethiopia. ${ }^{13}$ This might be because nurses who have not taken training on infection control are less updated with information, which hinders updating their knowledge.

The study was conducted in a small sample size so, the generalizations of the findings are limited. Also, the participant practice could be checked using a direct/indirect observational checklist by the researcher herself rather directly questioning them to see the actual implementation of practices by nurses towards the catheter care.

\section{CONCLUSIONS}

The overall level of knowledge among the nurses is inadequate towards the prevention of catheter-related urinary tract infection and this is reflected in their attitude; as their overall attitude is negative. The statistically significant factors that affect the level of knowledge are: age, professional qualification, designation, current area of practice, previous information, or training on CAUTI prevention. As nurses are an important group of players in the health 
care team, this study shows that it is important to provide the best appropriate educational program and training regarding the preventive measures of hospital and device-associated infections and they should be trained about when and how to avoid unnecessary urinary catheter use without a doctor's order which may decrease the risk of CAUTI.

\section{ACKNOWLEDGMENTS}

We are thankful to all the Nursing staffs of the College of Medical Sciences and Teaching Hospital for their valuable support and time during data collection.

\section{REFERENCES}

1. Centers for Disease Control and Prevention (CDC). Catheter-associated urinary tract infections (CAUTI). 2015 Oct 16 [updated2017 July 19; cited 2019 Feb 25]. [Link]

2. Hooton TM, Bradley SF, Cardenas DD, Colgan R, Geerlings SE, Rice JC, et al. Diagnosis, prevention, and treatment of catheter-associated urinary tract infection in adults: 2009 International clinical practice guidelines from the infectious diseases society of America. Clinical Infectious Diseases. 2010 Mar; 50(5):625-663. DOI: 10.1086/650482[Link]

3. Prajapati DK, Gupta A, Prajapati R, Gupta A.Epidemiological study of catheter-associated urinary tract infection (CAUTI) in surgical patients in Gajra Raja Medical College, Gwalior, India. IOSR Journal of Dental and Medical Sciences. 2015 Sep; 14(9):77-81. [Link]

4. P Leelakrishna, Rao K. A study of risk factors for catheter-associated urinary tract infection. International Journal of Advances in Medicine. 2018; 5(2):334. [Link]

5. Parajuli NP, Acharya SP, Dahal S, Singh JP, Mishra SK, Kattel HP, et al.
Epidemiology of device-associated infections in an intensive care unit of a teaching hospital in Nepal: A prospective surveillance study from a developing country. American Journal of Infection Control. 2017 Sep; 45(9):1024-1029. [pubmed]

6. Purbia V, Vyas H, Sharma M, Rathore D. A study to assess the effectiveness of planned teaching programme on knowledge of staff nurses regarding the prevention of urinary tract infection among patients with an indwelling catheter. International Journal of Scientific and Research Publication. 2014 Jan. [Link]

7. Mukakamanzi J. Knowledge, attitude and practices of nurses towards the prevention of catheter-associated urinary tract infection in selected referral hospitals in Rwanda [Master's Thesis]. College of Medicine and Health Sciences: University of Rwanda; 2017. [Link]

8. Algarni SS, Sofar SM, Wazqar DY. Nurses' knowledge and practices toward the prevention of CAUTI at King Abdulaziz university hospital. Journal of Health, Medicine, and Nursing. 2019; 4(1):39-62. [Link]

9. Kumar P, Medikonda R. Knowledge 
regarding catheter care among staff nurses. International Journal of Applied Research. 2015; 1(8):182-186. [Link]

10. Shah M, Wahab F, Ullah F, Gul U, Aziz A, Ullah Z. Infection control in the use of urethral catheter: knowledge and practices of nurses. American Journal of Advanced Drug Delivery. 2017 Jan; 05(01).DOI: 10.21767/2321-547X.1000006[ Link]

11. Kaur J, Kumar CN. Adoption of guidelines on knowledge and practice regarding care of urinary catheter in situ among staff nurses. Int J Health Sci Res. 2017 Oct; 7(10):152-157. [Link]
12. Shehzadi A, Ali A, Bhatti R, Yaseen I. Knowledge and attitude of nurses towards the prevention of catheterassociated urinary tract infection in ICUS of a public hospital Lahore. Saudi Journal of Nursing and Health Care [Internet]. 2018 [cited 2019 Feb 25]; 1(3):119-124.

13. Desta M, Ayenew T, Sitotaw N, Tegegne N, Dires M, Getie M. Knowledge, practice and associated factors of infection prevention among healthcare workers in Debre Markos referral hospital, Northwest Ethiopia. BMC Health Services Research. 2018; 18(1). [Link]

Citation: K.C. R, Dhakal B. Knowledge, Attitude and Practice on Prevention of Catheter-Associated UTI Among Nurses of a Tertiary Care Hospital. JCMS Nepal. $2021 ; 17(1) ; 61-8$. 